\title{
Seydikemer İlçesi (Muğla) Topraklarının Özellikleri ve Kullanımı Üzerine Bir Değerlendirme
}

\author{
Recep Bozyiğit ${ }^{1 *}$ \\ ${ }^{1}$ Necmettin Erbakan Üniversitesi, Ahmet Keleşoğlu Eğitim Fakültesi, Coğrafya Eğitimi, Konya, Türkiye (ORCID:0000-0002-9790-1168)
}

(İlk Geliş Tarihi 12 Şubat 2020 ve Kabul Tarihi 19 Mart 2020)

(DOI: 10.31590/ejosat.702654)

ATIF/REFERENCE: Bozyiğit， R. (2020). Seydikemer İlçesi (Muğla) Topraklarının Özellikleri ve Kullanımı Üzerine Bir Değerlendirme. Avrupa Bilim ve Teknoloji Dergisi, (18), 695-706.

$\ddot{\mathbf{O} z}$

Seydikemer İlçesi Topraklarının Özellikleri ve Kullanımı Üzerine Bir Değerlendirme, adlı çalışma yöredeki toprakların fiziksel, kimyasal ve kullanım özelliklerini ortaya çıkarmayı hedeflemektedir. İlçe toprakları hem yerinde tetkik edilmiş, hem de farklı noktalardan toprak örnekleri alınmıştır. Daha sonra alınan toprak örneklerinin laboratuvar ortamında analizleri yapılarak fiziksel ve kimyasal özellikleri ortaya çıkarılmıştır.

Seydikemer İlçesi toprakları, pedogenetik özelliklerine göre yapılan sınıflamada üst kategori tasnifine tabi tutulmuştur. Buna göre yörede altı büyük toprak grubu yer almaktadır. Bu topraklardan en yaygın olanı kırmızı Akdeniz topraklarıdır. Bunu kahverengi orman, kolüvyal, kireçsiz kahverengi orman, alüvyal ve kırmızı kahverengi orman toprakları takip eder. Yöre topraklarında ana kaya, iklim ve topoğrafyanın etkileri görülmektedir. Ofiolitlerin yaygın olduğu sahalarda kireçsiz kahverengi orman; kalkerin yaygın olduğu yerlerde kırmızı Akdeniz toprakları; topoğrafyanın düz veya hafif eğimli yerlerinde ise alüvyal ve kolüvyal topraklar yer alır.

Seydikemer İlçesi'nin farklı yerlerinden alınan toprak örneklerinde: kil \%14-42, mil \% 13.4-40.8, kum \%27.2-60.8, toplam tuz 0.01-0.06, $\mathrm{pH}$ 7.5-7.8, kireç $\left(\mathrm{CaCO}_{3}\right)$ 4.0-44.2, fosfor $\left(\mathrm{P}_{2} 2 \mathrm{O}_{5}\right)$ 0.45-8.47, organik madde 0.70-2.61 arasında değişmektedir. Bu değerlere göre ilçe topraklarında organik madde ve fosfor azlığı, kireç ve yer yerde kil oranlarının yüksekliği dikkati çekmektedir. Fosfor ve organik madde miktarının yetersiz olduğu yerlerde, yetiştiriciliği düşünülen bitkilere makro ve mikro besin elementi takviyesi(gübreleme) önerilir. Ayrıca kil oranı yüksek araziler de drenaj sorunu da görülebileceğinden bahçe kurulumu öncesi drenaj sorununun giderilmesi gerekir. Seydikemer İlçesi topraklarının jeodinamik problemleri arasında erozyon, heyelan, taşkın ve kıyı kumulları yer almaktadır.

Anahtar Kelimeler: Seydikemer, Toprak, Fiziksel, Kimyasal, Özellik

\section{An Evaluation on the Properties and Use of Soils of Seydikemer District (Muğla)}

\begin{abstract}
An evaluation on the Properties and Use of Soils of Seydikemer District aims to reveal the physical, chemical and usage properties of the soils in the region. District lands were investigated on site, and soil samples were taken from different points. Later, the soil samples were analyzed in a laboratory environment, and their physical and chemical properties were revealed.

Seydikemer District lands were subjected to the upper category classification in the classification made according to their pedogenetic features. Accordingly, there are six large soil groups in the region. The most common of these lands is the red Mediterranean lands. This is followed by brown forest, colluvial, limeless brown forest, alluvial and red brown forest soils. In the territory of the region, the effects of bedrock, climate and topography can be seen. Lime-free brown forest in areas where ophiolites are common; red Mediterranean soils where limestone is common; alluvial and colluvial soils are located on the flat or slightly sloping parts of the topography.

The soil samples taken from different parts of Seydikemer District range as follows: Clay 14-42\%, mil 13.4-40.8\%, sand 27.2-60.8\%, total salt 0.01-0.06, pH 7.5-7.8, lime $\left(\mathrm{CaCO}_{3}\right)$ 4.0-44.2, Phosphorus $\left(\mathrm{P}_{2} \mathrm{O}_{5}\right)$ 0.45-8.47, and organic matter 0.70-2.61. According to these values, the scarcity of organic matter and phosphorus in the district lands, high levels of lime and clay in places are notew orthy. In places where the amount of phosphorus and organic matter is insufficient, macro and micro nutrient supplements (fertilization) are recommended to the plants that are considered to be cultivated. In addition, since the problem of drainage can be observed in the lands with high clay rate, drainage problem should be eliminated before the garden installation.

Some of the geodynamic problems of the territory of the Seydikemer District are erosion, landslide, flood and coastal dunes.
\end{abstract}

Key Words: Seydikemer, Soil, Physical, Chemical, Properties

\footnotetext{
* Sorumlu Yazar: Necmettin Erbakan Üniversitesi, Ahmet Keleşoğlu Eğitim Fakültesi, Coğrafya Eğitimi, Konya, Türkiye, ORCID:0000-0002-97901168,fethiye.kemer@gmail.com
} 


\section{Giriş}

Toprak; oluşumu, özellikleri, kullanım ve korunması ile her geçen gün önem kazanan taşkürenin önemli bir parçasıdır. Toprak, "arzın dışını ince bir tabaka halinde kaplayan, kayaların ve organik maddelerin türlü ayrışma ürünlerinin karışımından meydana gelen, içerisinde ve üzerinde geniş canlılar alemi barındıran, bitkilere durak yeri ve besin kaynağı olan, belli oranlarda su ve hava kapsayan üç boyutlu bir varlıktır" şeklinde tanımlamaktadır (Akalan, 1983). Toprağı oluşturan farklı görüşler olmasına karşın(Dokuchaev, 1886; Jeny, 1941; Crocker, 1952; Mückenhausen, 1962) ortak görüş iklim, ana materyal, topoğrafya, canlılar ve zamandır(Mater, 1998-14-15; Efe 2010:179). Bunlardan ana materyal, topografya ve zaman pasif; iklim ve canllar ise aktif faktörlerdir(Efe, 2010:179).

Tüm bu süreçler dikkate alındığında farklı toprak tipleri ortaya çıkmaktadır. Bu toprak tiplerini ortaya koyan çeşitli sistem ve sistemlerin geliştirildiğini görmekteyiz(Dokuchaev, 1882-1900; Marbut, 1927; Baldwin, M-Kellog,C.E.-Thord, J.,1938; FAO ve UNESCO, 1971-1981; Atalay, 2011; Atalay, İ.-Gökçe Gündüzoğlu, A.,2015): Çeşitli faktörleri dikkate alınsa da Seydikemer toprakları pedogenetik ve fiziksel özelliklerini esas alan üst kategoride; büyük toprak grupları düzeyinde adlandırılarak incelenmiştir(T.C. Tarım ve Orman Bk., Topraksu Gn. Müd.1984:2).

Toprak değişkenliği farklı zaman ve mekan ölçeğinde etkili olan doğal ve antropolojik süreçlerin bir sonucudur. Topraklardaki bu doğal değişkenlik, jeolojik ve toprak oluşum süreçlerinden kaynaklanmaktadır(Efe, 1999). Antropojenik değişkenlik ise insanların arazi kullanımının bir sonucu olarak ortaya çıkmaktadır.

Toprak kaynakları potansiyelinin korunmasında en önemli konu mevcut durumun tespiti ve ileri projeksiyona yönelik tutumların saptanarak alınabilecek önlemlerin ortaya konulmasıdır(Bağdatlı, M.C.-İstanbulluoğlu, A.-Bayar, N.A. 2014:17). Toprakları koruma ve kullanma, toprağın özelliklerini iyi kavramaktan geçer. Bu açıdan Seydikemer İlçesi toprakları araştırma konusu olarak seçilmiştir. Seydikemer İlçesi, Türkiye'nin güneybatısında Muğla İli’ne bağlı bir ilçedir. Toprakları Akdeniz Bölgesi'nin Antalya Bölümü'nde yer almaktadır (Harita 1). Seydikemer İlçesi'nin kuzeyinde Altınyayla, kuzeydoğusunda Korkuteli ve Elmalı; güneydoğusunda Kaş, güneyinde Akdeniz, batısında Fethiye ve kuzeybatısında da Çameli yer alır. İlçe, $36^{\circ} 17^{\prime}-37^{\circ} 02^{\prime}$ kuzey enlemleri ile $29^{\circ} 07^{\prime}-29^{\circ} 48^{\prime}$ doğu boylamları arasında, 2028,37 km² yüz ölçümüne sahiptir.

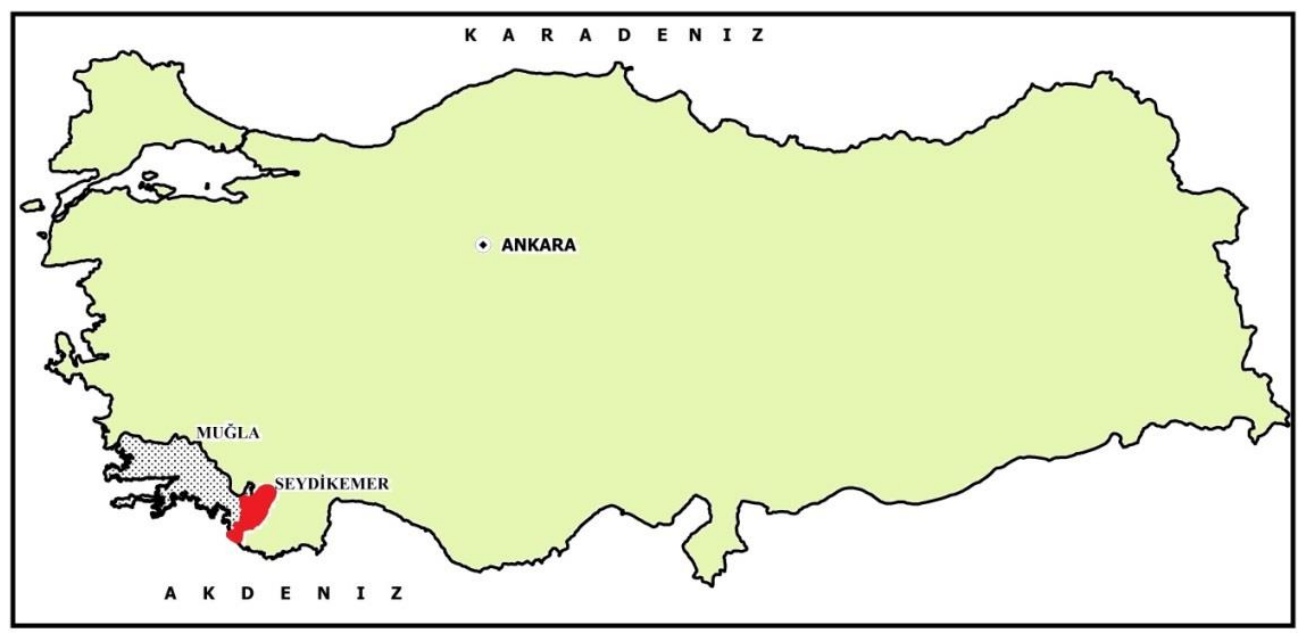

Harita 1. Seydikemer Illçesi’nin Yeri

\section{Materyal ve Metot}

Seydikemer İlçesi Topraklarının Özellikleri ve Kullanımı Üzerine Bir Değerlendirme konulu çalışmada esas metot, gezigözlem metodu olmuştur. Farklı tarihlerde gerçekleşen arazi çalışmalarında alınan toprak örneklerinin laboratuvar ortamında analizleri yapılarak bir takım bulgulara ulaşılmıştır. Daha sonra elde edilen bulgular ve Topraksu Genel Müdürlüğü tarafından hazırlanan haritalar 1şı̆̆ında Seydikemer İlçesi'nin büyük toprak tipleri, özellikleri ve kullanımı değerlendirilmiştir.

Bu çalışma da: 1/100 000 topoğrafya haritalarının O 22, O 23, P 22, P 23 ile 1/25 000 ölçekli O $22\left(a_{3}, b_{3}, b_{4}, c_{1}, c_{2}, c_{3}, c_{4}, d_{2}, d_{3}\right)$, O $23\left(a_{1}, a_{4}, d_{1}, d_{2}, d_{4}\right)$, P 22( $\left.a_{2}, a_{3}, b_{1}, b_{2}, b_{3}, b_{4}, c_{1}, c_{2}\right)$ Fethiye paftaları; 1/100 000 ölçekli Türkiye Jeoloji Haritasının Fethiye L8, M8 paftaları (Şenel, 1997a, 1997b) ve büyük toprak tiplerinin dağılışını gösteren T.C. Tarım Orman ve Köy İşleri Bakanlığı, Topraksu Genel Müdürlüğ̈̈’nün 1/100 000 ölçekli haritasının ilgili paftaları kullanılmıştır.

\section{Araştırma Sonuçları ve Tartışma}

\subsection{Toprak Özelliklerini Etkileyen Faktörler}

Seydikemer İlçesi'ni oluşturan arazide Likya Napları ile tanımlanan allokton konumlu litolojik birimler, farklı ortamda birikmiş tortul kayalar ve nispeten yaygın olan ofiolitik birimler görülür. Yüksek kesimlerde yaygın olarak kalker, dolomitik kalker, ofiolitik melanj, e-ISSN: $2148-2683$ 


\section{European Journal of Science and Technology}

harzburgit, dünit; ova ve vadi tabanı ile çevresinde kiltaşı, kumtaşı, konglomera ve kalkerler yer almaktadır(Şenel vd., 1989, 1995). İlçe sahasında karbonatı kayaçların fazlalığı toprakların kireç oranlarının yüksek olmasında etkili olmuştur.

Seydikemer İlçesi’ni oluşturan arazi, aynı zamanda tektonik hatlarla parçalanmıştır. Genel doğrultuları kuzey-güney olan ana fayların yanında tali faylar da yer almaktadır(Şenel vd., 1995). Eşen Çayı Vadisi’nin güney kesimlerinde basamaklı bir özellik gösteren bu faylar, aynı zamanda büyük toprak gruplarının dağılışını da etkilemektedir.

Seydikemer İlçesi'nin en yüksek kesimleri, kuzeyinde ve doğusunda bulunmaktadır(Harita 2). Kuzeyinde, Boncuk Dağları ve onun uzantıları yer almaktadır. Eşen Çayı vadi tabanından oldukça eğimli bir şekilde yükselen Boncuk Dağları'nın güneybatı uzantıları Karadağ (2233 m), Yüylükbaşı T.(2418 m), Kocaeren T. (2295 m), Karadiş T.(2235 m) ve Teşnekçibaşı T. (1722 m)'dir. Doğusunda yer alan Akdağ üzerindeki önemli yükseltiler ise Ziyaret T. (2591 m), Oluklusivrisi T.(2156 m), Elbisdağı (2596 m), Erendağı (2677 m), Çatal T. $(2534 \mathrm{~m})$, Dumlu T. $(2458 \mathrm{~m})$, Atkuyruksalmaz T. $(2879 \mathrm{~m})$ ve Uyluk T. (3024 m)'dir. Yüksek kesimler aynı zamanda eğim değerlerinin fazla olduğu yerlerdir. Bu kesimlerde eğim $11^{\circ} 18^{\prime} 35^{\prime \prime}$ ile $30^{\circ} 57^{\prime} 49^{\prime \prime}$ arasında değişmektedir. Toprak oluşumunun son derece yavaş olduğu bu kesimler genellikle çılak kayalık yüzeyler olarak dikkati çeker(Harita 3). İlçenin kuzeybatı kesimi kuzey-güney istikametinde, Çaldağ (2184 m), Rahat Dağı $(1259 \mathrm{~m})$, Haticeana Dağı $(1079 \mathrm{~m})$ ve Dokuzkızlan T. $(924 \mathrm{~m})$ uzanmaktadır. Özellikle Söğ̈̈tlüdere Mahallesi'nin kuzey ve kuzeydoğusunda eğimi $30^{\circ} 57^{\prime} 49^{\prime \prime}$ ile $38^{\circ} 39^{\prime} 35^{\prime \prime}$ arasında değişen sahalar yer almaktadır. Bu kesimler de de çıplak kayalık sahalar görülmektedir(Harita 3). Seydikemer'in güneybatısında Babadağ (1975 m), Almacık Dağı, Avdankaya T. (1152 m) ve Sandakdağı (1009 m) yer almaktadır. Yükseltinin en az olduğu yerler ilçenin güneyindeki delta ovası boyunca uzanan kıyı bölgesidir. Eğim buralarda da $00^{\circ} 00^{\prime} 00^{\prime \prime}$ ile $02^{\circ} 51^{\prime} 44^{\prime \prime}$ arasında değişmektedir. Seydikemer İlçesi'nde delta sahası dışında eğimin en az olduğu kesimler Yukarı Seki Ovası, Aşağı Seki Ovası, Ortaköy Ovası, Seydikemer Ovası, Kabaağaç-Kadıköy ovalarıdır. Bu ovalarda alüvyal ve kolüvyal topraklar görülmektedir.

Seydikemer İlçesi’ni oluşturan arazi, genelde engebeli bir özellik göstermekle beraber yukarı ve aşağı olmak üzere iki bölümde tetkik edilebilir (Harita 2). Yukarı bölümde; Seki Platosu, aşağı kesimde de Eşen Çayı Vadisi yer almaktadır. Seki Platosu sahasında kalan Karanlık Dere Kanyon Vadisi'nin devamı olan Eşen Çayı Vadisi, birbirinden eşik sahaları ile ayrılan ovaların yer aldığı bir oluşum olarak dikkat çeker. Kuzey-güney istikametinde, Ortaköy, Seydikemer, Kabaağaç-Kadıköy, Delta(Kumluova ve Karadere) ovaları yer almaktadır(Harita3). Birer birikim alanı olan ovaların kenar kesimlerdeki alüvyal yelpazelerde, kanal dolgularına rastlanmaktadır(Kazancı, N-Uysal, F., 2008:28).

İlçe topraklarının bugünkü özellikleri kazanmasında etkili olan bir diğer unsur da hidrografik faktörlerdir. Bunların başında da yüksek kesimleri sık bir şekilde vadilerle yarmış olan Eşen Çayı ve kolları gelir. Eşen Çayı ve kolları, toprakların kum oranının fazlalığında, erozyon, taşkın ve hareketli kumulların oluşumunda etkilidir. Etüt sahasının kuzeyinde Yazır, güneyinde de Girdev gölleri bulunmaktadır.

Seydikemer İlçesi, her ne kadar Akdeniz Bölgesi sınırları içinde kalsa da sahile yakın kesimlerde Akdeniz iklimi etkili olmakta, iç bölgelere doğru karasal iklime geçiş görülmektedir. İlçede yağışlar, yüksek dağlık alanlar ve platolarda genellikle kar; diğer yerlerde yağmur şeklindedir. Etüt sahasının engebeli olmasından dolayı ortalama sıcaklık ve yağış değerleri farklılık göstermektedir. Kıyıya yakın kesimlerde yıllık ortalama sıcaklık (Eşen $18.2^{\circ} \mathrm{C}$, Seydikemer'de $17.4{ }^{\circ} \mathrm{C}$ ) ve yağışın (Eşen, $915.3 \mathrm{~mm}$, Seydikemer $812.5 \mathrm{~mm}$ ) yüksek; iç kesimlerde ise (Seki'de yıllık ortalama sıcaklık $12.7^{\circ} \mathrm{C}$; yıllık ortalama yağış $453.6 \mathrm{~mm}$ ) düşük olduğu tespit edilmiştir (D.M.İ., 2015). Rüzgâr yönü mevsimlere göre değişmekle beraber hakim rüzgâr yönü kuzey sektörlüdür. İklimin ilçe toprakları üzerindeki etkisi; fazla yıkanma sonucunda; toplam tuz ve organik maddenin azlığına yol açması şeklinde kendini göstermektedir.

Etüt sahasının ova ve vadi tabanlarında maki bitki toplulukları yer almaktadır. 1000 metrenin üzerindeki yükseltilerde makiler ortadan kalkmakta; bunların yerine kızılçam (Pinus brutia), köknar(Abies cilicica) ve meşe(Quercus ssp.) türleri almaktadır. 1300-1450 metrelerde karaçam (Pinus nigra), meşe(Quercus ssp.), karma ormanı; 1450-2000 m arası sedir (Cedrus libani); 2000-2200 m arasında da adi ardıç (Juniperus communis) toplulukları bulunmaktadır. Yörede doğal bitki örtüsünün gür ve örtülülük oranının yüksek olmasının (\%71.12), yüzey erozyonunun etkisini azalttığı görülmektedir.

Seydikemer İlçesi topraklarında, 65 mahalle yerleşmesinde toplam 61653 kişi (TÜíK, 2019) yaşamaktadır. Bu nüfusun geçim kaynakları arasında tarım ve hayvancılık önemli yer tutmaktadır. İlçede toplam arazinin \%25.47'si (51 $665 \mathrm{Ha})$ tarım, \% 71.12'si (144 $247 \mathrm{Ha}$ ) orman ve çayır-mera arazisi ve \% 3.41’i (6 $915 \mathrm{Ha}$ ) ürün getirmeyen arazilerden oluşmaktadır (Seydikemer İlçe Tarım Müd. 2014). Tarım arazilerinin büyük çoğunluğu Eşen Çayı Vadi Tabanı ile Seki Ovası'nda yer almaktadır. Ancak vadi yamaçlarında yer alan Bekçiler, Yayla Karaçulha, Doğanlar, Yayla Zorlar, Yayla Ören, Kınık, Söğütlüdere, Dereköy, Çökek, Kayacık, Yakaköy, Bağlıağaç, Arsaköy, Kayadibi, Kabaağaç mahalleleri tarım faaliyetleri için orman ve çayır-mera arazisi üzerinde baskı oluşturmaktadır.

Günümüzde Seydikemer İlçesi topraklarının karşı karşıya kaldığı sorunlar arasında erozyon, hareketli kumullar, heyelanlar, taşkın ve arazi kullanımındaki yanlışlıklar yer almaktadır. 


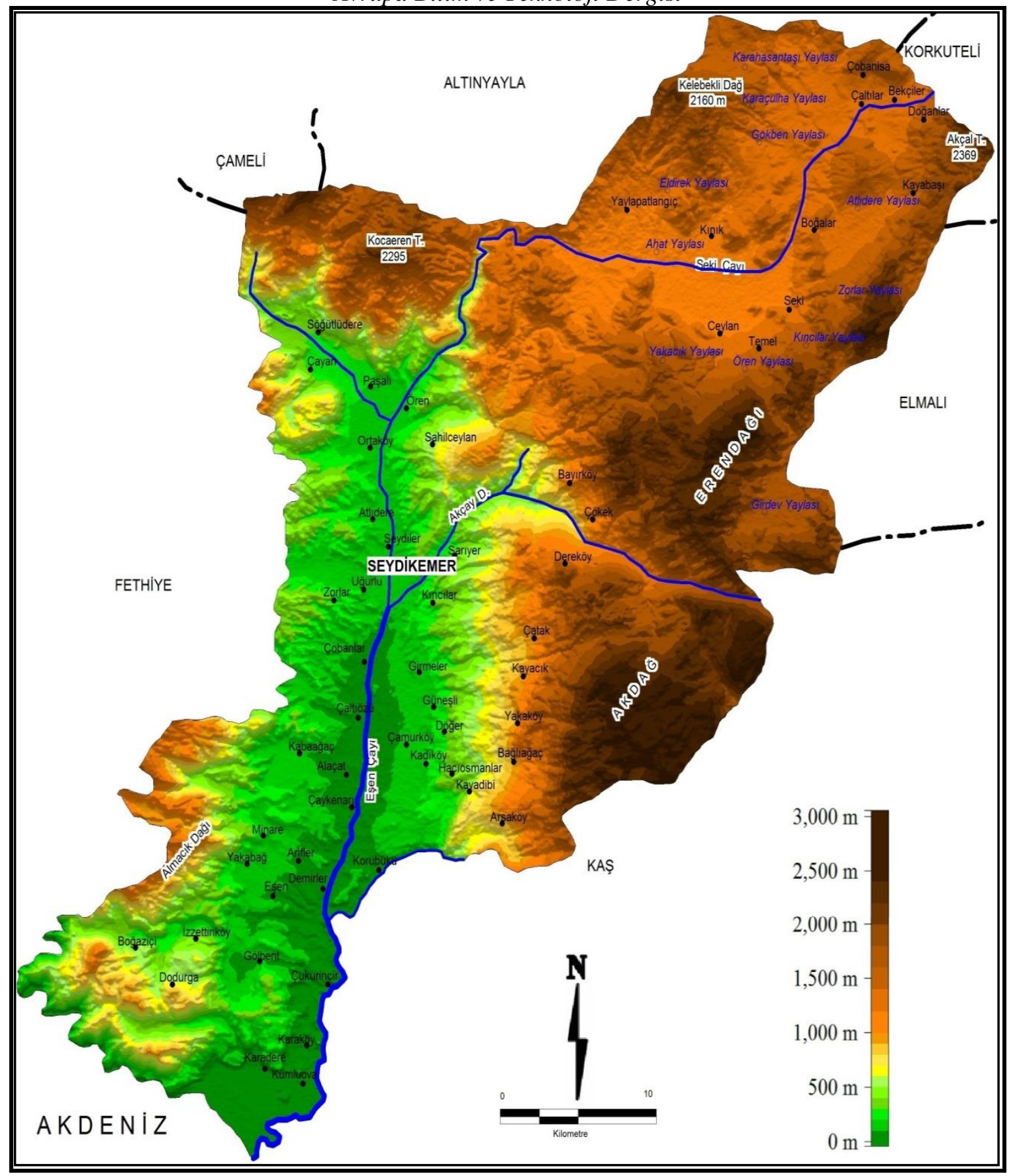

Harita 2. Seydikemer İlçesi'nin Yeryüzü Şekilleri Haritası

\subsection{Toprak Tipleri ve Kullanımı}

Seydikemer İlçesi’ndeki topraklar, pedogenetik özelliklere göre yapılan sınıflamada üst kategori tasnifine tabi tutulmuştur. Üst kategori tasnifi büyük toprak grubu seviyesinde olmuştur. Tasnifi yapılan büyük toprak gruplarının fiziksel ve kimyasal analizlerine göre bölge topraklarının genel karakterleri tespit edilmiştir. Buna göre yörede altı büyük toprak grubu yer almaktadır (Harita 3).

\subsubsection{Alüvyal Topraklar}

Alüvyal topraklar, akarsu orijinli depozitlerden meydana gelen, profilinde çeşitli katlar bulunduran genç ve derin topraklardır. A ve C horizonlarına sahiptirler. Eşen Çayı'nın oluşturduğu alüvyonlar; delta sahasında, diğer tali derelerin oluşturduğu alüvyonlar ise; birikinti koni ve yelpazelerinde bulunur. 


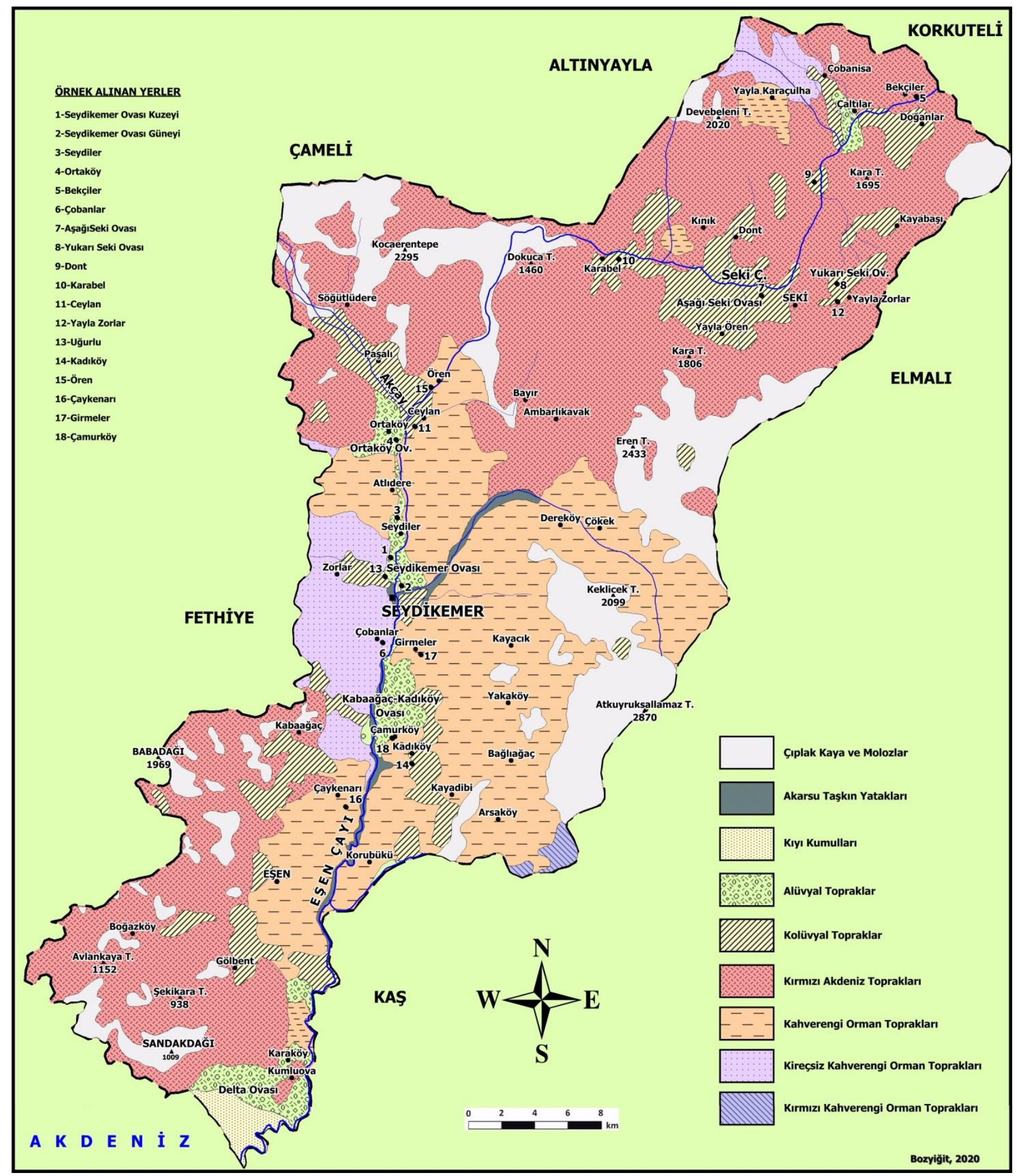

Harita 3. Seydikemer İlçesi’nin Toprak Haritası (T.C., Tarım Orman ve Köy İşleri Bak., Topraksu Gn. Müd. Yay. 1984'den değiştirilerek).

Akarsuların oluşturduğu alüvyonlar; düz, düze yakın eğimli sahalar ile düzgün topografyada yer alırlar. Bu nedenle alüvyaller genellikle geçirgenlikleri normal olan, iyi drenajlı, tuzluluk ve alkalilik problemleri olmayan, kuru ve sulu tarım topraklarıdır. Bunlarda kaba bünye bazı hallerde problem teşkil edebilir. Bu toprakların fiziksel ve kimyasal özelliklerini, alüvyonun kaynaklandığı ana materyalin özelliği, taşıma ve birikme esnasında meydana gelen değişmeler etkilemektedir. Alüvyal topraklar gerek yatay, gerekse dikey yönde devamlı bir değişme göstermektedir. Özellikle dikey yönde farklı horizonlar kendini belli etmektedir. Kumlu bir seviyeden killi bir seviyeye, kireçli bir kattan kireçsiz bir diğer kata geçilmesi gibi. Profil dâhilinde, karbonat dağılışı, pH durumunu, organik madde miktarı, katyon değişme kapasitesi ve tekstür düzensiz bir dağılış göstermemektedir (T.C. Tarım Orman ve Köy İşleri Bak., Topraksu Gn. Müd. Yay. 1984). 


\section{Avrupa Bilim ve Teknoloji Dergisi}

Seydikemer İlçesi'ndeki alüvyal topraklarda; kum miktarlarının oldukça fazla, bünye yönünden killi-tın (CL), kumlu-tın (SL) ve kumlu-killi-tınlı (SCL) oldukları tespit edilmiştir. Bu topraklarda kum oranının fazla olması, akarsu kökenli olmalarından kaynaklanmaktadır. Sahadaki alüvyal toprakların permeabilitesi yüksek, su tutma kapasitesi düşüktür. Su tutma kapasitesinin düşük olması, kil ve organik madde azlı̆̆ından kaynaklanmaktadır(Bozyiğit, 1997:17).

Bu toprakların geniş yayılım gösterdiği sahalardan alınan örneklerin (Harita 3) analiz sonuçlarına göre; kil yüzdesinin en fazla olduğu yer, Seydikemer Ovası kuzeyindeki (Killik Mevkii) topraklardır. Organik madde miktarının en fazla olduğu yerin ise Seydiler toprakları olduğu anlaşılmıştır(Tablo 1). Kil ve organik madde fazlalığı, söz konusu sahalarda toprağın su tutma miktarını olumlu yönde etkilemiştir. Bu toprakların diğer bir özelliği ise bazik karakterde olmalarıdır. pH 7,8'dir. Kireç oranı değişkendir. Kireç oranı Seydiler ile Seydikemer Ovası kuzeyindeki (Killik Mevkii) topraklarda yüksek olmasına karşın Seydikemer Ovası güneyinde düşüktür. Kireç oranının yüksek olması ana kayadan kaynaklanmaktadır.

İlçede alüvyal topraklar; Eşen Çayı'nın akış istikametinde Çaltılar, Ortaköy, Seydiler, Seydikemer, Çukurincir, Karaköy, Kumluova ve Karadere çevresinde(Fotoğraf 1) önemli yayılış gösterir. Bu topraklarda, sebze, meyve, örtü altı yetiştiricilik, pamuk, susam, mısır, zeytin, nar ve buğday tarımı yaygın olarak yapılmaktadır.

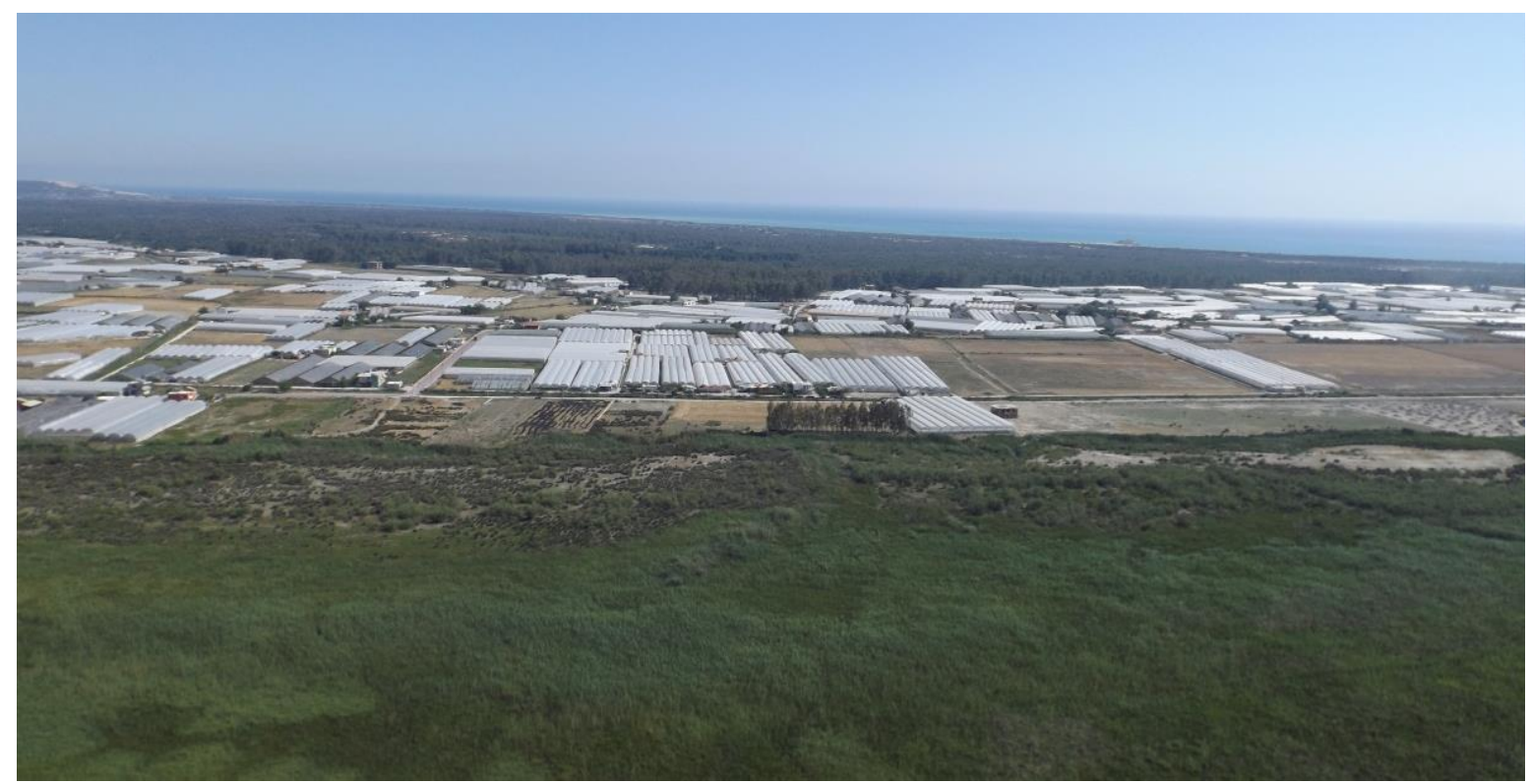

Fotoğraf 1. Eşen Çayı Deltası'ndaki Alüvyal Topraklar(Kumluova-Karadere), Örtü Altı Yetişstiriciliğin Yoğun Olarak Yapıldı̆̆ Sahalardan Birisidir.

Tablo 1. Seydikemer İlçesi’nde, Örnek Alınan Yerlerin Toprak Özellikleri

\begin{tabular}{|c|c|c|c|c|c|c|c|c|c|c|}
\hline $\begin{array}{c}\text { Toprak Örneği Alınan } \\
\text { Yerler }\end{array}$ & $\begin{array}{l}\text { Rakım } \\
(\mathbf{m})\end{array}$ & $\begin{array}{c}\text { Kil } \\
\%\end{array}$ & $\underset{\%}{\text { Mil }}$ & $\underset{\%}{\text { Kum }}$ & Bünye & $\begin{array}{c}\text { Toplam } \\
\text { Tuz }\end{array}$ & pH & $\begin{array}{c}\text { Kireç } \\
\left(\mathrm{CaCO}_{3}\right)\end{array}$ & $\begin{array}{l}\text { Fosfor } \\
\left(\mathrm{P}_{2}^{\left.2 \mathrm{O}_{5}\right)}\right.\end{array}$ & $\begin{array}{c}\text { Organik } \\
\text { Madde }\end{array}$ \\
\hline Seydikemer Ov. Kuzeyi & 160 & 32.0 & 40.8 & 27.2 & $\mathrm{CL}$ & 0.05 & 7.8 & 30.8 & 8.01 & 1.06 \\
\hline Seydikemer Ov. Güneyi & 155 & 21.6 & 24.0 & 54.4 & SCL & 0.02 & 7.8 & 6.7 & 2.75 & 0.70 \\
\hline Seydiler & 186 & 14.0 & 26.2 & 59.8 & SL & 0.01 & 7.8 & 26.8 & 4.58 & 1.24 \\
\hline Ortaköy & 215 & 28.0 & 31.6 & 41.0 & $\mathrm{CL}$ & 0.03 & 7.8 & 13.4 & 0.45 & 0.89 \\
\hline Bekçiler & 1310 & 32.8 & 26.2 & 41.0 & $\mathrm{CL}$ & 0.05 & 7.7 & 21.4 & 8.47 & 2.61 \\
\hline Çobanlar & 11 & 35.6 & 25.6 & 38.8 & $\mathrm{CL}$ & 0.05 & 7.7 & 24.1 & 0.45 & 1.6 \\
\hline AşağıSeki Ov. & 1150 & 42.0 & 18.0 & 40.8 & $\mathrm{C}$ & 0.06 & 7.7 & 44.2 & 0.45 & 0.89 \\
\hline Yukar1 Seki Ov. & 1420 & 25.6 & 14.0 & 60.8 & SCL & 0.06 & 7.7 & 5.3 & 3.10 & 0.70 \\
\hline Dont & 1230 & 31.6 & 15.4 & 53.8 & SCL & 0.05 & 7.5 & 8.0 & 3.20 & 0.70 \\
\hline Karabel & 1100 & 14.0 & 23.2 & 62.8 & SCL & 0.01 & 7.7 & 38.8 & 2.75 & 0.77 \\
\hline Ceylan & 255 & 27.2 & 25.8 & 47.0 & $\mathrm{CL}$ & 0.03 & 7.8 & 41.2 & 2.29 & 1.35 \\
\hline Yayla Zorlar & 1150 & 30.0 & 23.0 & 47.2 & SCL & 0.04 & 7.7 & 32.7 & 6.87 & 1.35 \\
\hline Uğurlu & 160 & 20.0 & 26.0 & 54.8 & SCL & 0.03 & 7.9 & 18.7 & 0.45 & 0.77 \\
\hline Kadıköy & 110 & 34.8 & 31.8 & 33.4 & $\mathrm{CL}$ & 0.04 & 7.7 & 37.5 & 2.75 & 1.06 \\
\hline Ören & 111 & 24.0 & 23.4 & 52.6 & SCL & 0.02 & 7.8 & 4.0 & 0.45 & 0.77 \\
\hline Çaykenarı & 95 & 27.6 & 13.4 & 59.0 & SCL & 0.05 & 7.7 & 33.5 & 1.14 & 0.95 \\
\hline Girmeler & 151 & 37.2 & 21.4 & 41.4 & $\mathrm{CL}$ & 0.06 & 7.7 & 26.8 & 2.29 & 0.90 \\
\hline Çamurköy & 120 & 33.6 & 23.6 & 42.8 & $\mathrm{CL}$ & 0.05 & 7.7 & 13.4 & 3.20 & 0.70 \\
\hline
\end{tabular}




\section{European Journal of Science and Technology}

\subsubsection{Kolüviyal Topraklar}

Kolüviyal topraklar sahada, yüzeysel akışla ve yan derelerin kısa mesafelerden taşıyarak eğimin azaldığı yerlerde depo ettiği materyallerden ibarettir.

Kolüviyal topraklar, alüviyal topraklara bitişik olarak alüviyallerle yüksek arazi toprakları arasında yer almaktadır. Tabii meylin çok az olduğu sahalarda bu iki toprak grubunun birbirine geçiş yaptığı görülür. Kolüviyal topraklar özellikle dağlık ve tepelik araziler içerisinde yer alan küçük depresyon sahalarında görülmektedir. Ayrıca dik yamaçların eteklerinde ve dar vadilerde az topraklı, taşlı ve molozlu olarak da görülürler (Fotoğraf 2).

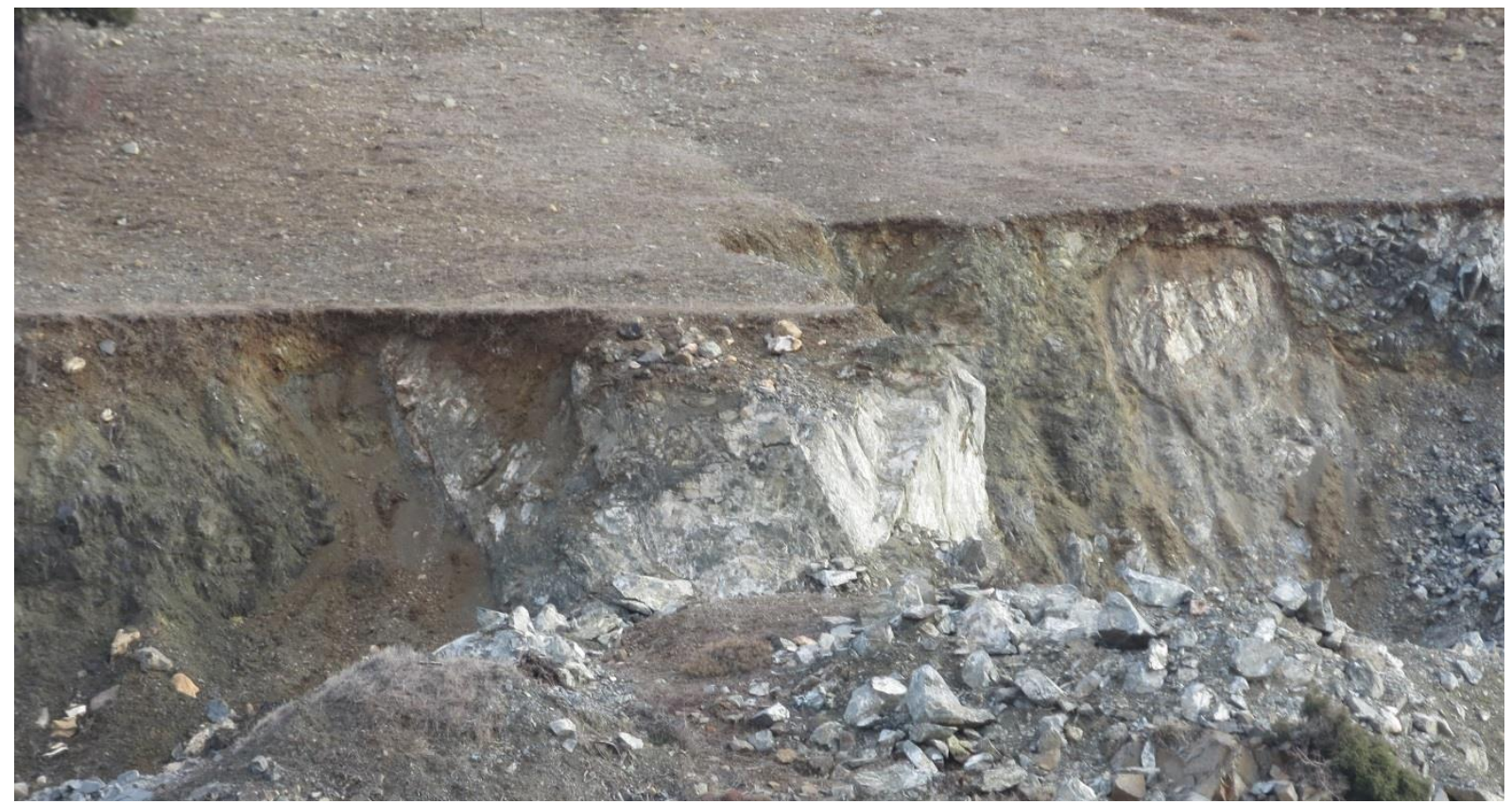

Fotoğraf 2. Dont Yaylası Kuzeyindeki Yarmada, Kesit Vermiş Kolüvyal Topraklar

Kolüviyal toprakların ana maddeleri, içinde bulunduğumuz jeolojik zamana ait muhtelif orijinli koluviyumlardır. Yakın mesafelerden taşınarak geldiğinden bilhassa alt katlarda orta ve kalın bünyelere sahiptir. Fizyolojik derinlikleri çok fazla olan bu topraklarda kil oranı değişken olmakla beraber ve kum miktarları (Yukarı Seki Ovası \%60,8, Karabel \%62,8, Dont 53,8, Uğurlu \%54,8) oldukça fazladır. Buna istinaden bu topraklarda bünye kumlu-killi-tın (SCL) veya killi-tın (CL) şeklindedir (Tablo 1). Kum miktarının fazla olması fiziksel parçalanma ve sürtünmenin etkisinden kaynaklanmaktadır. Drenajları iyi, permeabilitesi düşüktür. İnfiltrasyon hızı bu topraklarda çok hızlıdır. Organik madde miktarı en az değerini Yukarı Seki Ovası ile Dont Yaylası $(\% 0,70)$ topraklarında gösterir. Kolüviyal toprakların hemen hepsinde bazla doygunluk tamdır ve pH: 7,7 civarındadır. Tuz ve fosfor yönünden fakir olan bu topraklar, kireç yönünden oldukça zengindir. Fosfor yönünden Dont Yaylası (3,20 kg/dek) ile Yukarı Seki Ovası (3,10 kg/dek.) orta, Yayla Zorlar (6,8 kg./dek) iyi, Uğurlu Ovası ise fakirdir $(0,45 \mathrm{~kg} / \mathrm{dek})$.

Kolüviyal topraklar kuru tarıma elverişliliği yanında su kanallarının yapımı ile sulu tarıma açılmıştır. Bu toprakların görüldüğ̈̈ yerler: Aşağı ve Yukarı Seki ovaları, Dont, Karabel, Kayabaşı, Paşalı, Kıncılar, Uğurlu, Gölbent ve Kabaağaç ovalarıdır(Harita 3). Kolüvyal topraklarda; arpa, buğday, mısır, tütün, zeytin, nar, meyve, sebze, susam, pamuk, fasulye yetiştirilmektedir.

\subsubsection{Kırmızı Akdeniz Toprakları}

Bu toprakları oluşturan ana materyal, Tersier'e ait sert kalkerlerin ayrışma ürünleridir. Topografya; dağlık ve arızalı, eğim ise; çok sarp ve diktir. Doğal bitki örtüsünü, orman ve makiler oluşturmaktadır. A horizon; çoğunlukla $10 \mathrm{~cm}$ kalınlıkta, nemli iken kırmızımsı,

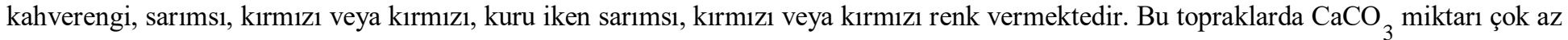
bulunmaktadır. Bu durum horizonda genel bir yıkanmanın olduğunu gösterir. Kolayca bulunan A horizonuna karşılık fazla eğimli, şiddetli erozyon ve taşlılık sebebiyle yok olan veya çok ince kalan B horizonunu tespit çoğunlukla mümkün görünmemektedir. Ped yüzeylerinde biriken kilin oluşturduğu parlak kil zarlarını görmek mümkündür. Profilde taş, çakıl ve mangan lekeleri görülmektedir. Bu toprakların $\mathrm{C}$ horizonunun ana materyalini sahadaki kil, konglomera ve ultrabazik kayaçlar oluşturmaktadır (T.C. Tarım Orman ve Köy İşleri Bak., Topraksu Gn. Müd. Yay. 1984).

$\mathrm{Bu}$ toprakların geniş yayılım gösterdiği sahalardan alınan örneklerin analiz sonuçlarına göre: bünye, genellikle kumlu (S), killi-tın (CL); kum oranı oldukça fazladır. Bekçiler civarından alınan toprak örneğinden çıkan sonuçta su tutma kapasitesi \% 55 civarındadır. Bunda kil ve organik madde miktarının fazla olması etkili olmuştur.

Kırmızı Akdeniz toprakları, Seydikemer yöresinde Akdeniz ikliminin hüküm sürdüğü sahalarda kızılçam, kızılçamların tahrip edildiği alanlardaki maki vejetasyonunun hakim olduğu alanlarda gelişme göstermişlerdir. Bu topraklara Seki ovalarını çevreleyen yüksek e-ISSN: 2148-2683 


\section{Avrupa Bilim ve Teknoloji Dergisi}

sahalarda(Fotoğraf 3), Kınık, Bekçiler, Ambarkavak, Boğazköy, Söğütlüdere ve çevresinde rastlanmaktadır (Harita 3). Ayrıca karstik çözülme sonucu gelişmiş olan dolin, uvala ve polyelerin tabanlarında karstlaşmanın ilerlemesine engel olan killi kireçtaşı veya marn tabakalarının üzerinde gelişme göstermiş̧tir. Seydikemer İlçesi’nde bitki örtüsünün daha çok tahrip edilmesi ile açığa çıkan kırmızı Akdeniz topraklarında buğday, arpa, anason, patates ve meyve yetiştiriciliği yapılmaktadır.

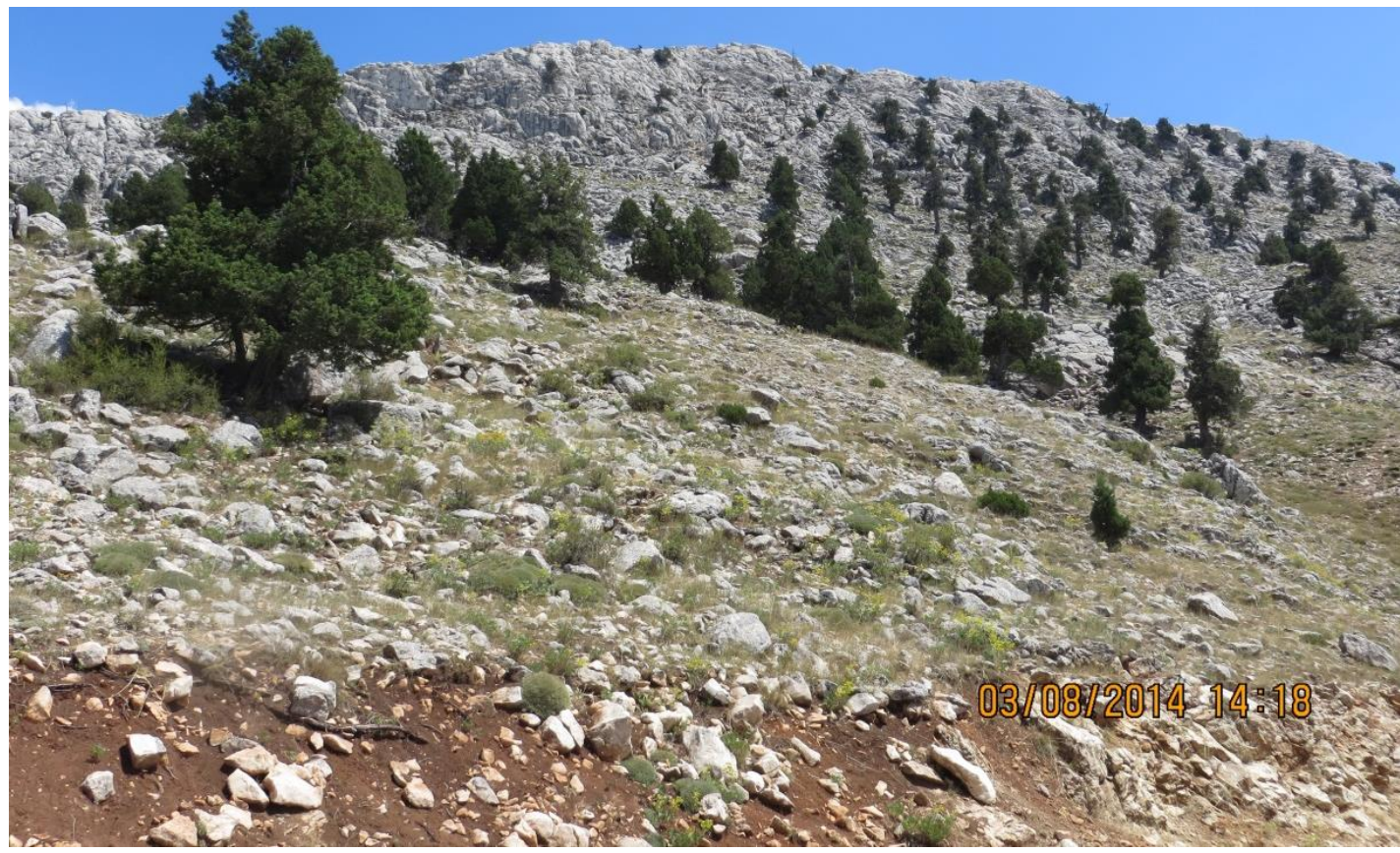

Fotoğraf 3. Akçal Tepe (2369 m) Güneyinde, Üst Kretase Yaşlı Çatlaklı Kalkerler Üzerinde Oluşmuş Kırmızı Akdeniz Toprakları

\subsubsection{Kahverengi Orman Toprakları}

Genellikle yıllık ortalama yă̆ışın $600-700 \mathrm{~mm}$, sıcaklığın $12^{\circ} \mathrm{C}$ 'nin üzerinde bulunduğu sahalarda görülmektedir. Doğal bitki örtüsü; özellikle yaprağını döken meşe, karaağaç, bodur meşe ve yaprağını dökmeyen çam türlerinden oluşmaktadır. Ana maddeleri çoğunlukla; Tersiyer'e ait kireçtaşı, marn, kalkerli kiltaşları ve kil çimentolu konglomeralardır. Eğim ve jeomorfolojik yapı toprak işlemesini kısıtladığından çoğunlukla orman ve mera olarak kullanılmaktadır. Ancak bu sahalarda eğim şartlarının elverdiği, orman ve fundadan açılmış sahalarda kuru tarım, Eşen Çayı vadi tabanında ise sulu tarım yapılmaktadır (T.C. Tarım Orman ve Köy İşleri Bak. Topraksu Gn. Müd. Yay. 1984).

Kahverengi orman topraklarının önemli problemleri ise; sığlık, fazla eğim, taşlılık ve erozyondur. Mekanik analiz sonuçlarına göre bünye; killi tın (CL) ve kumlu-killi-tın (SCL)'dır. Bu topraklarda kil yüzdesi diğer fraksiyon üyelerine göre biraz fazladır. Bundan dolayı bu toprakların suyu bağlama kuvvetleri fazla olup, yüzde su miktarları iyidir. Permeabilitesi normal olup, infiltrasyon hızları iyi, organik madde miktarları düşüktür. PH: 7,7 civarında ve baziktir. Tuz ve fosfor yönünden de fakir olan bu toprakların suni gübre ile takviye edilmesi uygundur.

Seydikemer İlçesi'nde kahverengi orman toprakları; Ören, Atlıdere, Girmeler (Fotoğraf 4), Kadıköy, Korubükü, Eşen, Çaykenarı, Arsaköy, Bağlıağaç, Yakaköy, Yayla Karaçulha, Dereköy ve Kayacık mahalleleri çevresinde yaygındır(Harita 3). Kahverengi orman topraklarında; sebze, meyve, örtü altı yetiştiricilik, pamuk, susam, mısır, zeytin, nar ve buğday tarımı yaygın olarak yapılmaktadır. 


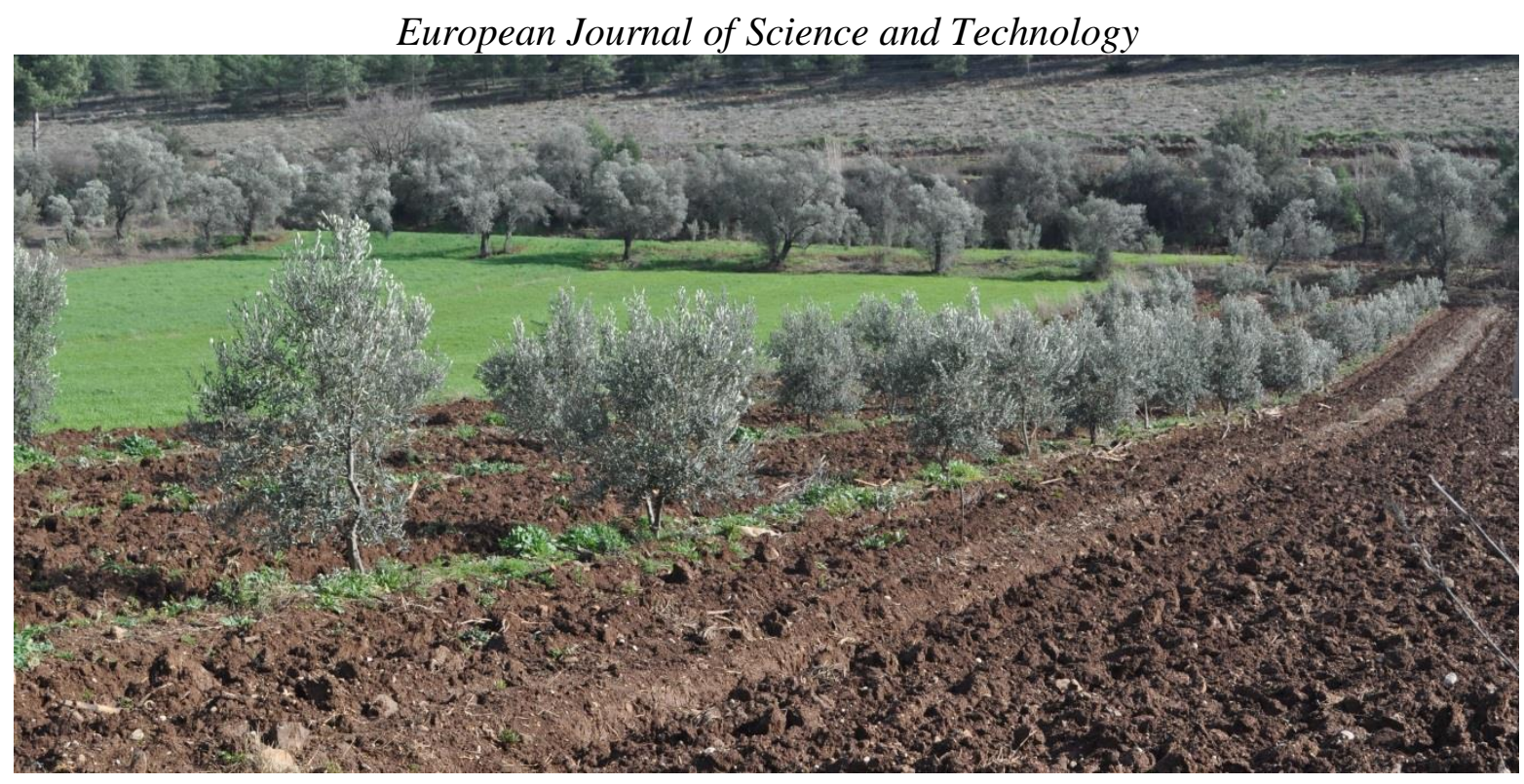

Fotoğraf 4. Girmeler Mahallesi, Çetilidüz Mevkiindeki Kahverengi Orman Topraklart

\subsubsection{Kireçsiz Kahverengi Orman Toprakları}

Bu topraklar, topoğrafyanın dağlık ve tepelik, eğimin $\% 12-30^{\circ}$ arasında olduğu kesimlerde görülmektedir. Eğim değerlerinin yüksek olması, toprağın tarım yönünden işlenmesini güçleştirmektedir. Genellikle bu topraklar üzerinde orman, funda ve maki formasyonları yer alır. Kuru tarım ve bağ-bahçe olarak kullanılan arazi az bir kısımda mevcuttur. Bu alanlar, toprak şartlarının elverdiği orman açmalarıdır. $\mathrm{ABC}$ horizonuna sahip zonal topraklardır. Eğimin fazlalığı ve bitki örtüsünün yetersizliği nedeniyle A horizonunun üzerinde organik horizonları her zaman görmek mümkün değildir. Bünye; tınlı veya siltti tın, yapı; orta derecede teşekkül etmiş bloktur. Kireç bu topraklara sekonder olarak gelmektedir. B horizonu 15-20 cm kalınlıkta olup renk nemli ve kuru iken grimsi kahverengidir. Oluşum faktörlerinden ziyade ana kayanın özelliğini taşıyan $\mathrm{C}$ horizonunun rengi nemli iken sarımsı kahverengi, kuru iken açık gridir. Bu topraklarda kil ve kum yüzdesi yüksek, bünye killi-tın (CL)'dır. Agregasyon olmadığından yapısızdır. En önemli özellikleri; eğim, sığlık, taşlılık ve erozyondur. Bundan dolayı bazı problemler görülmektedir (T.C. Tarım Orman ve Köy İşleri Bak. Topraksu Gn. Müd. Yay. 1984).

Kireçsiz kahverengi orman topraklarının bulunduğu sahalardan alınan numuneler sonucunda toprağın su tutma oranının yüzde 55 olduğu tespit edilmiştir. Bu durum kil ve mil oranı ile ilgilidir. Çünkü aynı topraklarda organik madde \%1,06 ile orta seviyenin altındadır. pH: 7,7 ve baziktir(Tablo 1). Fosfor dekara $0,45 \mathrm{~kg}$ olup zirai yönden fakirdir. Toprağın fosforlu gübrelerle takviye edilmesi gerekir.

Bu topraklara; Yayla Karaçulha Mahallesi'nin kuzeyi, Seydikemer İlçe merkezi ile Çobanlar Mahallesi'nin batı kesimlerinde rastlanır(Harita 3). Kireçsiz kahverengi orman topraklarında kızılçam, kızılçamın tahrip edildiği sahalarda maki bitki topluluğuna ait türler, sebze, meyve, örtü altı yetiştiricilik kısmen mısır, susam yetiştirilmektedir.

\subsubsection{Kırmızı Kahverengi Orman Toprakları}

Bu topraklar, Arsaköy'ün güneydoğusunda oldukça dar bir sahada görülürler. Kalker, kumtaşı, silttaşı yer yer de konglomera ana kayası üzerinde oluştukları görülmektedir. A (B) C profilli topraklar olmasına karşın saha çalışmalarında ince A horizonu ve onun altında B horizonu olduğu gözlenmiştir. Oldukça eğimli topoğrafyadaki topraklar üzerinde seyrek adi ardıç topluluğu görülmektedir.

\subsection{Seydikemer Topraklarının Sorunları}

Seydikemer İlçesi topraklarının jeodinamik problemleri arasında; erozyon, heyelan, taşkın ve kıyı kumulları yer almaktadır.

\subsubsection{Erozyon}

Seydikemer İlçesi’nde düz veya düze yakın vadi ve ova tabanlarındaki topraklar daha az erozyona uğrarken; bu kesimlerin çevresindeki yüksek kesimlerde daha şiddetli erozyon görülmektedir.

İlçenin yüksek dağlık kesimler ve platoların farklı litolojik birimlerden oluşması erozyona hız vermiş, farklı aşınım alanları meydana gelmiş, çözülme enkazı materyal akarsularla taşınarak erozyona süreklilik kazandırmıştır. Ayrıca çeşitli sebeplere bağlı olarak orman yangınları ve buna ilaveten yakacak ihtiyacının karşılanmasının bir sonucu olarak doğal zemin gevşetilmiş, erozyona hazır hale getirilmiştir. Eşen Çayı, Deliçay (Akçay) ve Akçay (Kıncılar D.)'ın mansap kısımlarındaki klastik depolar erozyonal faaliyetin en belirgin delili olarak görülmektedir (Bozyiğit, 2018:423).

\subsubsection{Heyelânlar}

Seydikemer'de heyelânlı sahalara; yüksek kesimlerle ova ve vadi tabanları arasındaki eğimin fazla olduğu yamaçlarda rastlanmaktadır. Bunlar pek yaygın değildir. Bugüne kadar meydana gelmiş heyelânların büyük bir kısmının yol yarmaları(Fotoğraf 5) ile 


\section{Avrupa Bilim ve Teknoloji Dergisi}

ormandan yer kazanmak üzere açılmış sahalarda meydana geldiği tespit edilmiştir. Seydikemer-Ceylan yolunun 8. km'sindeki yol yarmasında Kretase yaşlı kalkerler üzerinde yer alan flişli serinin yer yer batıya doğru kaydığı gözlenmiştir. Ayrıca Seydikemer’i Antalya'ya bağlayan karayolunun 5. km'sindeki Sarıyer mevkiinde denge açısı bozulan Eosen fliş serileri ana kayadan doğudaki Akçay Deresi'ne doğru kaymakta ve zaman zaman karayolu trafiğini aksatmaktadır. Seydikemer-Antalya karayolunun 12. km'sinde Bayır Mahallesi'ne bağlı Kirsecik Mevkii'ndeki bir bölüm arazide, 1978-79 kışında meydana gelen heyelânda can kaybı olmamakla beraber, bazı evlerin hasar gördüğ̈̈ tespit edilmiştir. Seydikemer-Antalya devlet yolunun 11. kilometresinde heyelan enkazı yolun tek şeritten sağlanmasına yol açmıştır (Bozyiğit, 1997). Seki Mahallesi'nin güneybatısındaki Kara T.(1806 m)'nin kuzey yamaçları kademeli faylarla parçalanmıştır. Aynı zamanda altta ofiolitler, üstte ise kalker tabakaların yer aldığı sahada dalgalı kayma yüzeyleri görülmektedir.

Havzada yüksek dağlık sahanın eteklerinde kurulmuş olan; Dereköy, Çökek, Kayacık, Yakaköy, Bağlıăgaç, Arsaköy, Seki, Yayla Ören ve Söğütlüdere mahalleleri heyelân riski taşıyan toprakların üzerinde yer almaktadır.

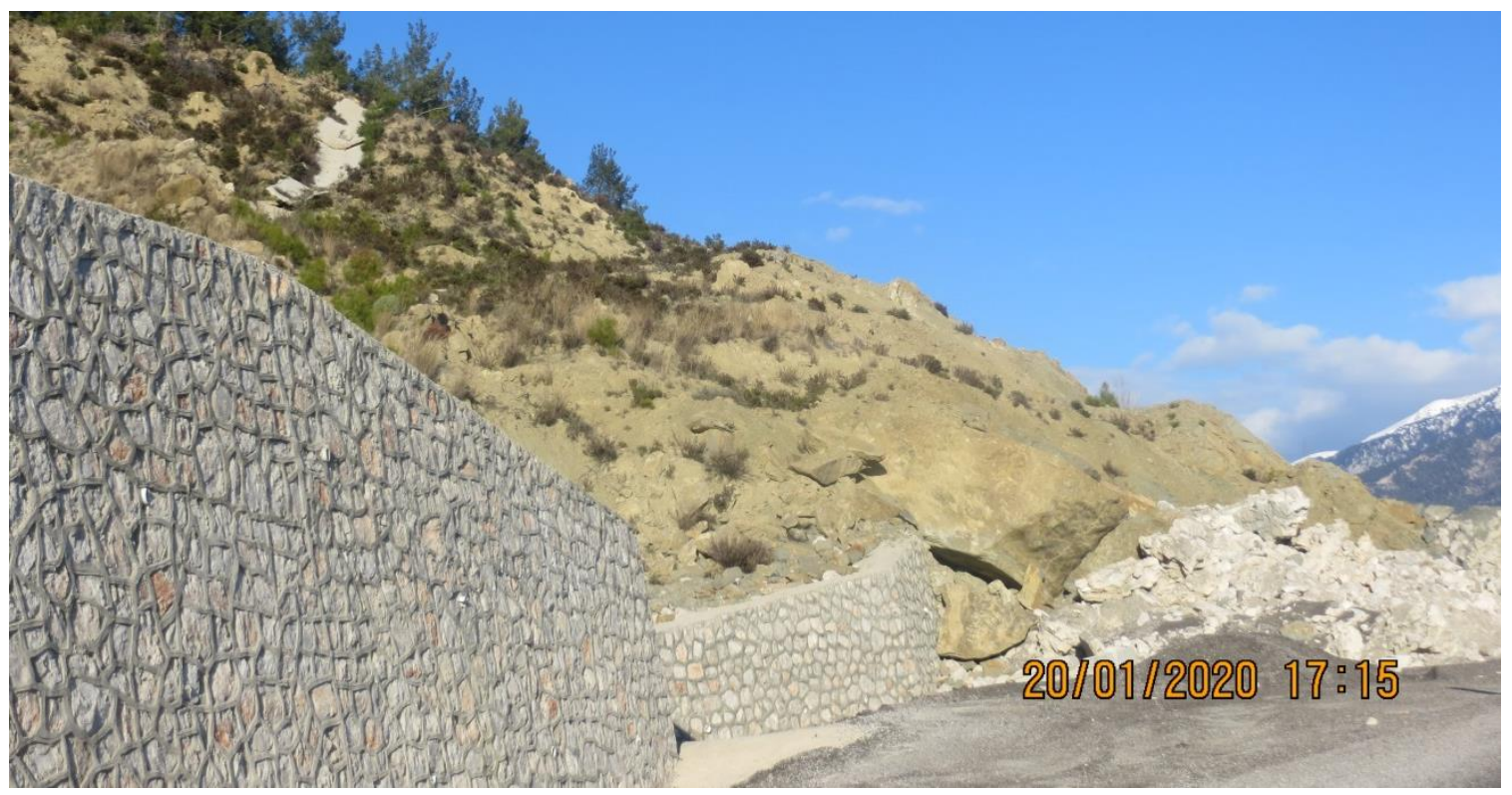

Fotoğraf 5. Seydikemer-Antalya Devlet Yolu Üzerinde Heyelan Enkazı

\subsubsection{Tașkınlar}

Seydikemer İlçesi'nde Ören-Kumluova mahalleleri arasındaki vadi tabanı ovaları(Harita 3), gerek sık sık kendilerini kat eden akarsuların; gerekse onların kollarını teşkil eden ve ovaların kenarında yer alan yüksek sahalardan doğan akarsuların taşkınlarına maruz kalırlar. Taşkın sonucunda bir kısım arazi su altında kalmakla birlikte siltasyon nebati toprağı maskelemiş̧ir.

Taşkınların meydana gelmesinde; havzanın topoğrafik özellikleri, jeolojik yapı, iklim ve insan faktörünün etkili olduğu görülür. Bu güne kadar taşkın yaşanan ovalar, Aşağı Seki Ovası, Ortaköy Ovası, Seydikemer Ovası, Kabaağaç-Kadıköy Ovası, Çukurincir Ovası ve Kumluova'dır.

\subsubsection{Kıyı Kumulları}

Seydikemer'de yer alan Eşen Çayı Delta Ovası'nın kıyısı boyunca kumullar yer alır(Harita 3). Batıda Zeytin Burnu'ndan, doğudaki Çayağzı'na kadar uzanan 6 km'lik mesafede bulunur. Hareketli kumullar, delta sahasının batı yakasında $4 \mathrm{~km}$ kadar içeriye sokulmuşlardır (Harita 3).

Kumul sahasını meydana getiren kumların kaynağı Eşen Çayı'nın getirdiği kum, silt ve kil boyutundaki malzemenin denize bırakılması, daha sonrada dalgalarla da delta cephesinin her iki tarafina doğru dağttılarak biriktirilmesi sonucunda teşekkül etmiştir (Fotoğraf 6). Zaman zaman hareketli olan kumulların yer değiştirmesini önlemek amacı ile T.C. Orman Bakanlığı tarafindan 1961 yılında erozyon önleme çalışmaları başlatılmış ve bu çalışmalar başarılı sonuçlar vermiş̧ir(Bozyiğit, 2018:435). 


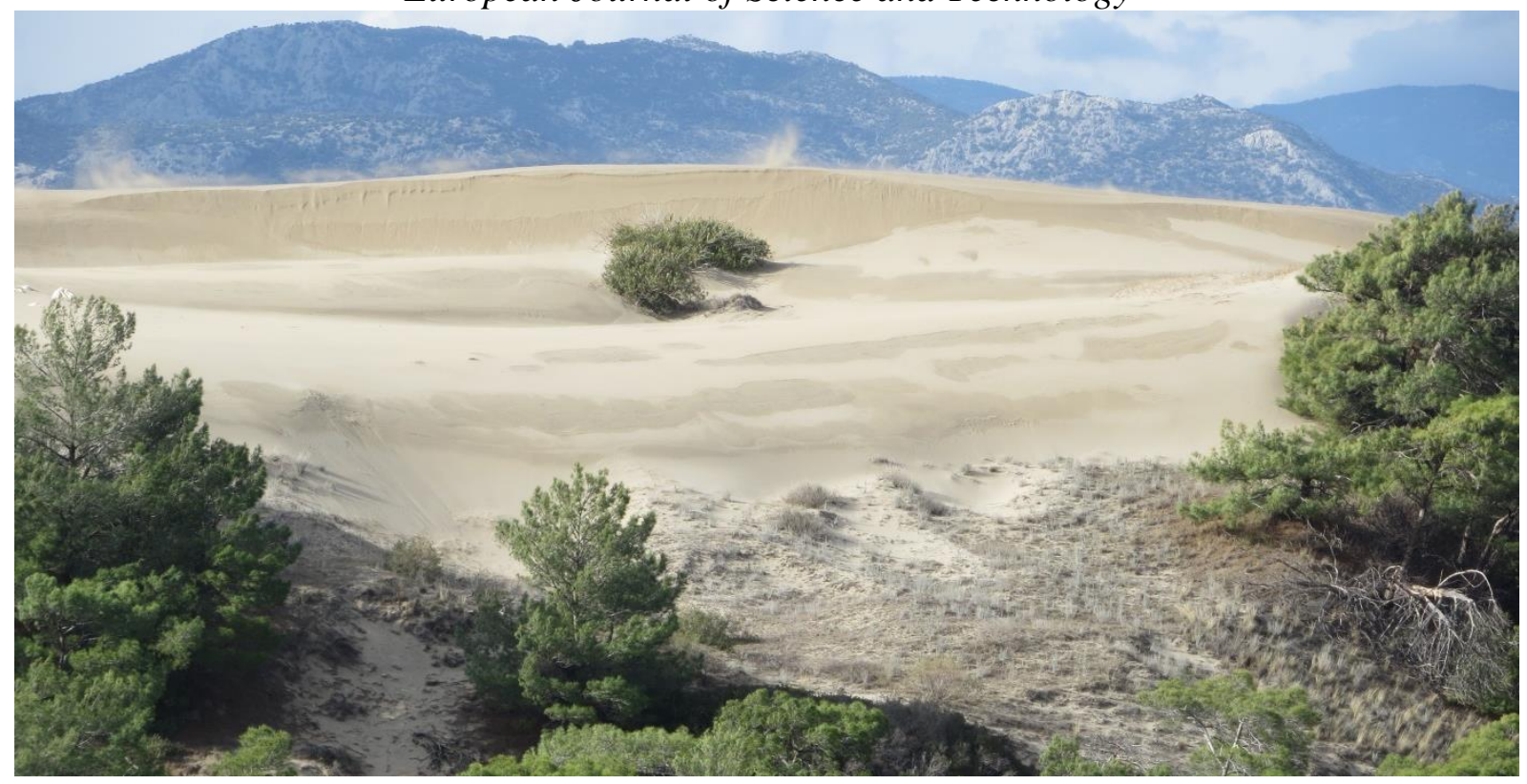

Fotoğraf 6. Eşen Çayı Deltası 'nda Yer Alan Kumullar, Zaman Zaman Hareketli Hale Geçebilmektedir. Bu Durum Yöredeki Tarım Arazilerini Tehdit Etmektedir.

\section{Sonuç}

Seydikemer İlçesi toprakları, pedogenetik özelliklerine göre yapılan sınıflamada üst kategori tasnifine tabi tutulmuştur. Buna göre yörede altı büyük toprak grubu yer almaktadır. Bu topraklardan en yaygın olanı, kırmızı Akdeniz topraklarıdır. Bunu kahverengi orman, kolüvyal, kireçsiz kahverengi orman, alüvyal ve kırmızı kahverengi orman toprakları takip eder. Yöre topraklarında ana kaya, iklim ve topoğrafyanın etkileri görülmektedir. Ofiolitlerin yaygın olduğu sahalarda kireçsiz kahverengi orman, kireçtaşının yaygın olduğu yerlerde kırmızı Akdeniz toprakları, topoğrafyanın düz veya hafif eğimli yerlerinde alüvyal ve kolüvyal topraklar yer alır. Organik madde bakımından fakir olan topraklarda en yüksek değere, Bekçiler Mahallesi topraklarında (2.61) rastlanmaktadır.

Seydikemer İlçesi’nin farklı yerlerinden alınan toprak örneklerinin laboratuvar analizlerinde: kil \%14-42, mil \% 13.4-40.8, kum \%27.2-60.8, toplam tuz 0.01-0.06, $\mathrm{pH} 7.5-7.8$, kireç $\left(\mathrm{CaCO}_{3}\right)$ 4.0-44.2, fosfor $\left(\mathrm{P}_{2} 2 \mathrm{O}_{5}\right)$ 0.45-8.47, organik madde 0.70-2.61 arasında değişmektedir. Elde edilen veriler ışı̆̆ında Seydikemer İlçesi topraklarının yüksek kireçli ve düşük organik maddeye sahip oldukları görülmektedir. Bölgedeki akarsular tarafından teşekkül ettirilen alüvyal toprakların tekstür analizleri incelendiğinde; genelde kumlu killi tın, killi tın bünyeye sahip oldukları görülmekte olup geçirgenlikleri yeterli, su tutma kapasitelerinin ise iyi derece de olduğu; tuzluluk problemi olmadığı anlaşılmaktadır. Alüvyal topraklar etkin toprak derinliği yeterli olan, çok yıllık bahçe bitkileri ve tarla bitkileri yetiştiriciliğine uygun topraklardır.

İlçe topraklarının genelinde organik madde eksikliğinin olduğu ve pH'nın yüksek olduğu görülmekte, kireç miktarının fazlalığından dolayı mikro besin elementi eksiklikleri ve azot eksikliğinin görülmesine sebep olmaktadır. Ayrıca fosfor miktarının yetersiz olduğu ve yetiştiriciliği düşünülen bitkilere makro ve mikro besin elementi takviyesi yani gübreleme yapılması zorunludur. Kil oranı yüksek araziler de drenaj sorunu da görülebileceğinden bahçe kurulumu öncesi drenaj sorununun giderilmesi gerekir.

Bölgedeki yüksek eğime sahip dik vadi ve tepe yamaçlarından yerçekiminin etkisiyle ve yüzey akışla tabana doğru biriken materyalin oluşturduğu kolüvyal topraklar etkili toprak derinliği genellikle sı̆̆g, organik maddece zayıf; fosfor, azot gibi makro besin elementlerince zayıf, kireç miktarı fazla topraklardır. Bu arazilerde bitkisel üretim verimini arttırmak için toprak strüktürünü geliştirici uygulamalar yapılmalı, özellikle organik maddenin arttırılması için yanmış ahır gübresi, humik asit vb. organik gübre takviyesi gerekir. Sı̆̆ toprak derinliği olan arazilerde ağaç dikimi yapmadan önce derin fidan çukurları açılarak fidan dikimi sonrası bu çukurlar toprakla doldurulmalı; eğimli yamaç arazilerde teraslama uygulaması yapılarak kök derinliği yüzlek olan zeytin, nar, badem gibi bahçe bitkileri ve tarla bitkileri yetiştirilebilir. Analiz sonuçlarına göre bu araziler yüksek kireç oranı içerdiğinden ve pH değerleri bazik karakterde olduğundan söz konusu arazilerde azot eksikliğini gidermek için amonyum sülfat gibi asidik karakterde gübreler kullanılması önerilebilir.

Seydikemer İlçesi topraklarını tehdit eden süreçler arasında erozyon, heyelan, taşkın, hareketli kumullar ve yanlış arazi kullanımı gelmektedir. Yörede su erozyonuna yol açan Eşen Çayı ve kolları aynı zamanda da taşkınlara sebebiyet vermektedir. Bu konuda taşkın kontrolü, baraj ve ağaçlandırma çalışmaları sürdürülmektedir. İlçe toprakları üzerinde heyelana uğramış ve uğrama riski bulunan sahalar mevcuttur. Bu sahalar lokal olmakla beraber zemin etütleri detaylı bir şekilde hazırlanmalı, riskli Yayla Ören, Söğütlüdere, Kayacık, Çökek, Dereköy mahalleleri sağlam zeminli yerlere çekilmelidir. Hareketli kıyı kumulları için T.C. Orman Bakanlığı tarafından 1961 yılında başlatılan çalışmalar neticesinde 3.5 milyon ağaç dikilmiş ve başarılı sonuçlar alınmıştır(Bozyiğit, 1991:57). Ancak ağaçlandırma sahasının yangın, kaçak kesim gibi riskler taşıması, zaman zaman Akdeniz üzerinden gelen hava kütlelerinin kumulları havalandırdığı görülmektedir. Bu konuda kumulların hareketlerinin izlenmesi ve üzerlerinin kumul şartlarına göre örtü bitkileri ile kaplanması önerilmektedir. Seydikemer İlçesi'nde mahalle yerleşmelerinin bir kısmı orman içi veya orman yakınında yer almaktadır. Bu mahallelerde 


\section{Avrupa Bilim ve Teknoloji Dergisi}

yaşayan halkın yakacak ihtiyacı, örtü altı yetiştiricilik ya da tarım faaliyetlerinden doğal bitki örtüsü zarar görebilmektedir. Bu durum eğimli sahalarda yer alan arazilerde toprak kayıplarına yol açmaktadır.

\section{Kaynakça}

Akalan, İ. (1983), Toprak Bilgisi, Ank., Üniv., Ziraat Fak., Yay no:878, Ankara.

Atalay, İ. (2011), Toprak Oluşumu, Sinıflandırması ve Coğrafyası, (5.Baskı), Meta Basım Matbaacılık Hizmetleri, İzmir.

Atalay, İ.-Gökçe Gündüzoğlu, A. (2015), Türkiye'nin Ekolojik Koşullarına Göre Arazi Kabiliyet Sinıflandırması, Meta Basım Matbaacıllık Hizmetleri, İzmir.

Bağdatlı, M.C.-İstanbulluoğlu, A.-Bayar, N.A. (2014), Toprak ve su Kaynakları Potansiyelinin Coğrafi Bilgi Sistemleri (CBS) Yardımıyla Belirlenmesi: Tekirdağ-Çerkezköy İlçesi Uygulaması, Afyon Kocatepe Üniversitesi, Fen ve Mühendislik Dergisi, Sayı:14, 17-25, Afyon.

Baldwin, M-Kellog, C.E.-Thord, J. (1938), Soil Clasification. Soil and Man, U.S. Dept. Agric. Ybk 979-1001 pp.illus.

Bozyiğit, R. (1991), Eşençay (Kocaçay) Deltasının Jeomorfolojisi ve Coğrafik Özellikleri, Selçuk Üniversitesi, Sosyal Bilimler Enstitüsü (Basılmamış Yüksek Lisans Tezi), Konya.

Bozyiğit, R. (1997), Eşen Çayı Havzası’nın Jeomorfolojisi, Marmara Üniversitesi, Sosyal Bilimler Enstitüsü (Basılmamış Doktora Tezi), İstanbul.

Bozyiğit, R. (2018), An Evaluation on the Hydrogeomorphological Properties of the Eşen Stream Basin, International Journal of Eurasia Social Sciences, Vol:9, Issue:32, pp.394-439.

Crocker, R.L. (1952), The plant factor in soil formation Australia., J.Sci. 21, 180-193.

D.M.İ. (2015): Fethiye ve Çevresindeki Meteorolojik İstasyonlarına Ait:

*Yıllık Meteoroloji Bültenleri.

*Günlük ve Aylık Meteoroloji Bültenleri.

Dokuchaev, V. V.,(1883), Russian Chernozem. Israel Program for Scientific Translations Ltd. (for USDA-NSF), S. Monson,

Dokuchaev, V.V. (1886), The Russian Stepppes., Dept. Agric. Min. Of Crown Domains fort he World's Columbian Exposition St. Petesburg, Rusia.

Efe, R. (1999), Güney Marmara Bölümü Batısında Toprak Oluşumunu etkileyen Coğrafi Faktörler ve Toprak Özellikleri, Türk Coğrafya Dergisi, Sayı 34, 193-209, İstanbul.

Efe, R.(2000), Biyocoğrafya, MKM Yayıncılık, Bursa.

FAO-UNESCO, (1971-1981), Soil map of the world. 1: 5000 000. Volume I. Legend. Prepared by the Food and Agriculture Organization of the United Nations. Unesco - Paris.

Jeny, H. (1941), Factors of Soil Formation A System of Quantitave Pedology, Dover Publications, Inc., New York.

Kazancı, N.-Uysal, F. (2008), Eşen Vadisi Pleyistosen Tortullarının Sedimantolojik İncelemesi, Ankara Üniversitesi, Bilimsel Araştırma Projesi, Kesin Raporu, Ankara.

Marbut, C.F.(1927), A Scheme for Soil Classification, First International Congress. Soil Scien, Protect 4, 1-31

Mater, B.,(1998): Toprak Coğrafyası, Çantay Kitabevi, İstanbul.

Mückenhausen, E.(1962), Enstehung, Eigenschaften und Sistematik der Boden der Bundersrepublik Deutschland. Frankfurt.

Seydikemer İlçe Tarım Müdürlüğ̈̈, (2014), Tarım ve Hayvancılık Verileri, Seydikemer.

Şenel, M.-Selçuk, H.- Bilgin, Z.R.-Şen, M.A.-Karaman, T.- Dinçer, M.A.- Durakan, E.- Arbaş, A.- Örçen, S.-Bilgin, C. (1989), Çameli (Denizli)- Yeșilova (Burdur)- Elmalı (Antalya) ve Dolayının Jeolojisi, MTA Rap no:9429 (Yayınlanmamıs), Ankara.

Şenel, M.-Akdeniz, H.-Öztürk, E.M.-Özdemir, T.-Kadınkız, G.-Metin, Y.-Öcal, H.- Serdaroğlu, M.-Örçen, S. (1995), Fethiye(MuğlaKalkan (Antalya) ve Kuzeyinin Jeolojisi, MTA, Enst. Jeo. Etüt, Dairesi Yayını, Ankara.

Şenel, M. (1997a), 1/100 000 Ölçekli Türkiye Jeoloji Haritaları No:2, Fethiye-L 8 Paftası, MTA, Jeoloji Etüt Dairesi, Ankara.

Șenel, M.(1997b), 1/100 000 Ölçekli Türkiye Jeoloji Haritaları No:4, Fethiye- M 8 Paftası, MTA, Jeoloji Etüt Dairesi, Ankara.

T.C. Tarım ve Orman Bakanlığı, Topraksu Gn. Müd.,(1984), Muğla İli Verimlilik Envanteri ve Gübre İhtiyaç Raporu, TOVEP Yayın No 15, Gn. Yayin no:15, Ankara.

TÜİK (2020): Nüfus İstatistikleri, Ankara. 